\title{
Rethinking construction in preschool: discerning didactic strategies in Swedish preschool activities
}

\author{
Johan Boström ${ }^{1}$ (D) Magnus Hultén ${ }^{2}$ M $\cdot$ Per Gyberg $^{3}$ (D)
}

Accepted: 16 June 2021 / Published online: 24 June 2021

(c) The Author(s) 2021

\begin{abstract}
Even though construction tasks have a long history as an activity in the Swedish preschool, technology as a content matter (e.g., construction) is relatively new. Hence, preschool teachers are generally unsure of the content of technology and how to handle it from a teaching perspective. Thus, there is need for deeper understanding of how construction tasks in preschool can be enacted and what kind of premises are offered to the children. To investigate this, we took our stance in activity theory and the concepts of mediating artifacts, rules and division of labour. This helped us discern what type of instructional practices that were enacted by preschool teachers when working with construction tasks. Activity theory in combination with thematic analysis helped us distinguish four general didactic actions that the teachers used to bring about the construction task- to engage, to guide, to coordinate, to show. These four strategies were then formulated into specific technology didactic actions through the perspectives of technology as product, process and concepts.
\end{abstract}

Keywords Preschool $\cdot$ Children $\cdot$ Construction $\cdot$ Technology $\cdot$ Activity theory

\section{Introduction}

\section{A shifting focus}

The world of today is an increasingly technological one. Citizens need vast technological skills in the form of a highly developed technological literacy to navigate their daily lives (Rohaan et al., 2010; Turja et al., 2009). This literacy is also a very important emancipatory

Johan Boström

johan.bostrom@lnu.se

Magnus Hultén

magnus.hulten@liu.se

Per Gyberg

per.gyberg@liu.se

1 Department of Physics and Electrical Engineering, Linnaeus University, S-351 95 Växjö, Sweden

2 Department of Social and Welfare Studies, Linköping University, S-601 74 Norrköping, Sweden

3 Department of Thematic Studies, Linköping University, S-581 83 Linköping, Sweden 
factor, without this knowledge the citizens will not be able to make deliberate democratic choices (Keirl, 2006). To shape this form of citizen, it is important to begin technology education as early as possible, preferably in preschool (Elvstrand et al., 2018; Stables, 1997). From an early age, children are exposed to technology (Campbell \& Jobling, 2008; Elvstrand et al., 2018). They observe and interact with their surrounding artifacts in order to make sense of the made world (Campbell, 2010). Preschool children often have an enthusiastic curiosity about the made world, which will help them develop their technological problem-solving skills. By engaging in technological tasks in preschool, the children will also get the opportunity to enhance their confidence in their technological capabilities and develop more general skills (e.g., working collaboratively in group settings) (Stables, 1997). In the following sections we will first describe technology education in preschool from a Swedish perspective. Secondly, we will take a look at the teacher's role during technology education in preschool in general and during construction activities in particular.

\section{Technology in the Swedish preschool curriculum}

Even though technology as an explicit content matter is a relatively recent addition to the Swedish preschool curriculum (Hallström et al., 2014), technology activities (i.e., crafts and creative tasks) have a long (well over 100 years) history in early childhood education (Parker-Rees, 1997; Turja et al., 2009). Technology activities which revolve around making and building with different kinds of materials is not a new concept in preschool (Bairaktarova et al., 2011; Sundqvist, 2019). These activities have been a part of the preschool practice for a long time in Sweden and can be traced back to the Fröbel-inspired Barnträdgårdarna at the beginning of the last century (Vallberg, 2002). These activities were often done within the home technology sphere (e.g. food technology, textile technology), as well as in the form of constructing with different materials. For example, building blocks, woodwork, sewing and household chores such as baking, were part of Barnträdgårdarna anno 1947 (Vallberg, 2002).

Teacher-led learning and explicit content matter (e.g., technology) has received a more pronounced role with every new revision of the Swedish preschool curriculum (Broström et al., 2015; Sheridan \& Williams, 2018). There is a strong focus on child centred "learning by doing" activities in preschool, and the view is often that teachers should not interfere in such activities or impose academic learning (Smith \& Pellegrini, 2008; Turja et al., 2009) on activities that are initiated by the children themselves (Pramling Samuelsson \& Asplund Carlsson, 2008). Free play and children's independent activities, which also can be traced to the Fröbel pedagogy, has been central in the Swedish preschool since the days of barnträdgårdarna (formed in the nineteenth century) (Caiman, 2015). DiGironimo (2011) has developed a lens through which technology education can be viewed. This lens consists of a prism describing the nature of technology (Fig. 1).

The three sides of the prism represent Technology as Artifacts, Technology as a Creation Process, and Technology as a Human Practice, while the top and bottom represent the History of Technology and its place in society; from past to present.

According to DiGironimo (2011) technology as artifacts revolve around the artifacts that people generally connect to technology (i.e., computers and machines). Technology as Human Practice encompasses the fact that Technology is value-laden, and not impervious to "political, cultural, societal, ethical, environmental, economical, and personal values and beliefs." (p. 1342). Technology as a Creation Process on the other hand describes both the design aspect of technology and the knowledge that is needed to perform the design 

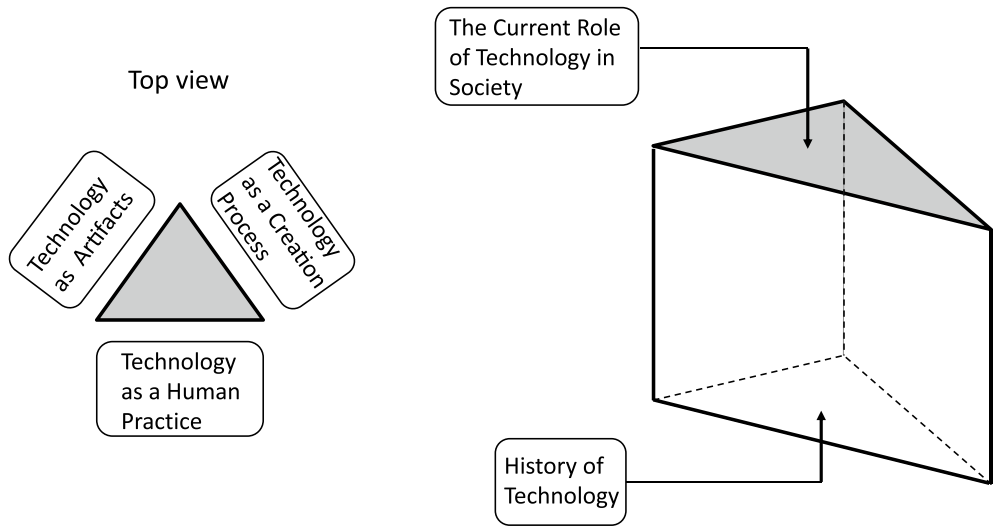

Fig. 1 The nature of technology (After DiGironimo, 2011, p. 1341)

process; this aspect includes skills and knowledge that is needed to engage in design activities in order to complete an envisioned end product.

Looking at the explicit technology goals of the Swedish preschool curriculum, it can be argued that they encompass DiGironimo's (2011) description of the Nature of Technology on one level or another. The curriculum states that each child should get the opportunity to develop their ability to:

- explore, describe with different forms of expressions, ask questions and discuss /.../ technology,

- discover and explore technology in everyday life,

- build, create and construct with the help of different techniques, materials and tools (Skolverket, 2018, p. 15).

\section{The importance of the teacher in construction activities in preschool}

As pertaining to the specific content matter of technology, Mawson (2013) concluded that the two most important factors for preschool children's understanding of technology seem to be teacher-led learning and the opportunity to revisit the learning situation (c.f. Stables, 1997; Sylva et al., 2007). Plowman et al. (2010) argue that children's operational skills can be developed through direct instructions and tutoring. However, Campbell (2010) points out that play provides opportunities for children's learning of technology, and according to Stables (1997), play helps children develop confidence and control when problem solving in technological tasks. Meanwhile, both Stables (1997) and Campbell (2010) also stress the importance of a teacher being on hand to provide prompts when the children face challenges that they cannot overcome by themselves.

When Sundqvist and Nilsson (2018) examined preschool teachers and childcare attendees view on technology education in preschool, they found that the respondents mainly saw their role in construction tasks as being the provider of the material and the ones setting up a creative environment for the children. Generally, the respondents did not see their role as the guiding and supporting hand in the children's technological learning. If the teachers just provide the venue (in a more hands-off kind of way), there is a risk of the children failing to achieve a successful outcome (Mawson, 2007). Jarvis and Rennie (1998) point out 
that children's ability to make sophisticated generalizations regarding technology is heightened if they get input from a teacher. In line with this, Turja et al. (2009) emphasize that teachers in early childhood education can help children develop technological skills and knowledge of "objects, materials, physical phenomena, process of productions, and technological ways of working" (p. 361). Fleer (2000) highlights teacher-led tasks as a way for teachers to give the children help in a more hands-on way (e.g., how material can be combined/joined together and/or shaped/formed). Campbell and Jobling (2008), on the other hand, highlight the importance of play in technological tasks in preschool, but it should be noted that they simultaneously emphasize that pre-planned tasks and appropriate guiding by the preschool teachers (i.e., guiding questions) can enhance the children's learning. Plowman et al. (2010), point out that the more hands-on ways of providing learning in preschool can often be seen as too "teacherly" by preschool teachers, but argue that children's operational skills can be developed by in-activity interactional guiding (i.e., direct instructions and tutoring).

A common technology theme in preschool revolves around construction, and these kinds of activities may help foster children's overall technological knowledge (Thorshag \& Holmqvist, 2017) as well as their understanding of the tools and material that are used for construction (Campbell \& Jobling, 2008). According to Parker-Rees (1997) a practical task (e.g., construction task) can be a starting point for discussing different ways of solving problems with the children, or as Parker-Rees (1997) states "learning to join cardboard boxes may not be an essential life-skill but it may provide opportunities for talking about ways of selecting from a range of possible strategies" (p. 6). Senesi (1998) found that even a relatively short construction task can advance children's knowledge of technological actions (e.g., joining materials) and everyday artifacts. Research has shown that children aged 3 through 5 may have problems selecting appropriate materials for construction work and when doing the actual construction, they lack "enough technical knowledge of how to join different types of materials" (Fleer, 2000, p. 56).

As with technology in preschool in general, one thing that stands out as important for the construction tasks is the active teacher. Stables (1997) stresses that the more support regarding "how things work, to make things work, and to create" (p. 51) children are given, "the better chance there is for their technological capability to prosper" (p. 51). SirajBlatchford and Siraj-Blatchford (1998) found that through teacher-led scaffolding, preschool children were able to produce more elaborate constructions than children who only had access to the material in a more traditional free play kind of environment. And Walan et al. (2020) point out that when it comes to preschool children's successful technological construction, guiding questions like "What kind of material could you use if you want to build a stable construction?" play an important role (cf. Campbell \& Jobling, 2008). To sum up, for the children to be able to learn technological skills, it is of importance that an active teacher is at hand during construction activities in order to help and guide them.

\section{Aim}

In summary, the requirements of content matter learning have increased in preschool. Previous research points to the importance of the preschool teacher being on hand, to guide and scaffold the children's technology learning. There is need for a deeper understanding of how preschool teachers can design and use construction tasks in preschool to support children's technological learning (Fleer, 2000), especially skills concerning "joining, assembling and using materials and tools" (Thorshag \& Holmqvist, 2018, p. 
57). Thus, there is a need of research regarding how preschool teachers support children's technological knowledge through their instructional practices.

Consequently, the aim of this study has been to discern how teachers frame and bring about the learning process in technology tasks in preschool. More specifically, the question guiding this study was: how can teachers support children in construction activities in preschool?

\section{Method}

The following section starts by taking a closer look at activity theory, which we used as a basis for generating reliable codes in the thematic analysis. Subsequently, we describe action research, which was the methodological framework of the overarching project this study was a part of. Then, we explain the process of thematic analysis, which was used to analyze the data. In this section, we also describe how activity theory was used to help the thematic analysis. And lastly, we describe the ethical considerations.

\section{Activity theory}

The analysis of this study has been inspired by activity theory. Activity theory is a framework for studying the ongoing material and socially mediated process of how people transform reality and themselves (Roth et al., 2012). It is a way of analysing and interpreting data that describes human discourse and behaviour and considers both social interactions and human conduct (Ekström, 2007; Engeström, 1993). The activity theory triangle can be used for analysing an educational setting (Hashim \& Jones, 2007). Sundberg et al. (2016) used group discussions and video recordings of preschool teachers from inhouse science activities to identify the different elements, relationships and contradictions central to understanding how these science activities were framed. The use of the activity triangle made it possible to detect structures and contradictions through a vast amount of data (Fig. 2).

Fig. 2 The activity system triangle (After Engström, 2001). The oval depicting the object is meant to show that "object-oriented actions are always, explicitly or implicitly, characterized by ambiguity, surprise, interpretation, sense making and potential for change" (Engström, 2001, p. 134)

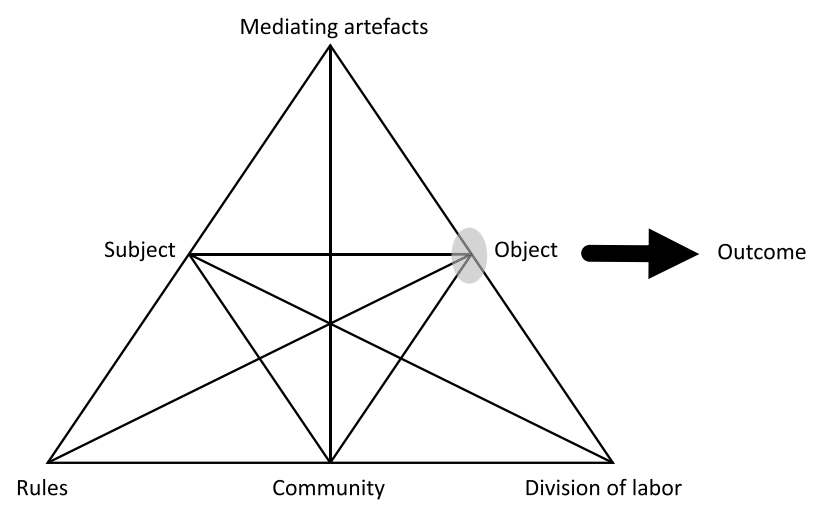




\section{Tools and semiotic signs}

The subject, in activity theory, is usually defined as an individual or a group and it is the actions of the individual or group that is the focus for analysis. The object is the issue that is being acted upon by the subject (i.e., the event-what is going on) (Daniels, 2004; Issroff \& Scanlon, 2002; Roth et al., 2012). This act is carried out by the subject based on a need (Van Aalsvort, 2004), and the subject acts on the object using mediating artifacts in form of tools (i.e., objects) and semiotic signs (i.e., tools for thinking) in order to transform it (Hardman, 2005; Issroff \& Scanlon, 2002). Plowman et al. (2010), who studied young children's learning with technology, state:

Technology-mediated learning is particularly appropriate for sociocultural analysis because of the centrality of tool-mediated action and the ways in which this can reveal learning. The 'tools' can be technological artefacts, in which case analysis focus on human-technology interaction, or dialogue and social practices, in which case the interactions are interpersonal (p. 94).

The concepts of tools and semiotic signs are not clear-cut. In defining the former, we (i.e., the authors of this article) equate tools with technological artifacts, that is: an object constructed by a thinking being, designed to have certain properties, solve human problems and fulfil human desires (Ginner, 1996; Säljö, 2008). These technological artifacts can be both material (e.g., a hammer or a whisk) or of a more abstract character-like a calendar, which depends on an intellectual system for counting days (Säljö, 2008). In defining the latter, we have taken our stance in a multimodal perspective. According to Halliday's (2014) systemic functional linguistics, which multimodality sprang from, language is a social semiotic system that humans use for meaning making. However, language isn't the only way of communicating, people also use facial expressions, head movements, gestures, and their surroundings as part of communicating (Flewitt et al., 2009). In multimodality, the concept of modality is used to describe these communicative modes (e.g., speaking, writing, gestures, picture, and attire) (Kress, 2009; Kress \& van Leeuwen, 2006; Scollon \& Scollon, 2009; Sellander \& Kress, 2010). Kress (2009) describes that a mode is always used in conjunction with at least one other mode in what is called modal ensembles, designed with a specific function or task in mind. A central principle of multimodality is that of mediated action, which refers to the mediated nature of social action. The social actions should be construed as happening between social actors and/or between the actor and the surroundings, which means that they can't be separated from the context they appear in Jewitt (2009) and Norris (2009). This interaction can be defined as "any action that a social actor performs in which the actor communicates a message. Such a message can be constructed intentionally or given off unintentionally" (Norris, 2009, p. 79). Hence, we view the mediating artifact of semiotic signs as the ways the preschool teachers interact with the children using modal ensembles in the object-oriented process.

\section{Rules}

The category named rules has to do with how the relationships in the system are regulated-what kind of implicit and explicit norms and regulations govern the possible actions and interactions within the activity system (Engeström, 1993; Hardman, 2005). Just like mediating artifacts is the mediating factor between subject and object, rules are the 
mediating factor between subject and community-where the community can be defined as the participants (individuals or subgroups) of the activity system, who share the general object (Daniels, 2004; Engeström, 1993; Issroff \& Scanlon, 2002; Murphy \& RodriguezManzanares, 2008). In our case the community can be defined as the pre-school teachers and children.

\section{Division of labor}

Finally, division of labor relates to both the division of tasks (horizontal division) in the community and the division of power and status (vertical division) (Engeström, 1993; Hardman, 2005). This can also be described as "the explicit and implicit organization of a community as related to the transformation process of the object into the outcome." (Issroff \& Scanlon, 2002, p. 78) and can be defined as the mediating factor between object and community (Issroff \& Scanlon, 2002). Even though both children and pre-school teachers (i.e., the two parts of the community) are encapsulated in the element of division of labor, in this study it has been the pre-school teacher's enactment of the tasks that has been under investigation. Thus, in this study, division of labor can be dubbed as the teacher's role.

\section{Action research}

This article is part of a larger action research project conducted during a period of 13 months at two preschools, with the same principal, in a medium-sized city in Sweden. Attendance in the project was voluntary and resulted in eight teachers, from five different units, forming the action research group along with author 1. Action research is a method for the research field and the practice (that the research field is studying) to meet on equal terms, where the practice identifies a problem within the own organization that can be solved with the help of the research field. This process can also contribute with new theoretical insights and research tools (Herr \& Anderson, 2005; Rönnerman, 2010, 2012; Westlander, 2006). Just like activity theory, action research can be placed in the sociocultural research sphere. Lev Vygotski, from whose writing's activity theory springs, and Kurt Lewin, who is recognized as the founder of action research, were inspired and influenced by each other's works (Somekh \& Nissen, 2011). Both activity theory and action research "share the fundamental assumption that knowledge emerges as aspects of practice (Somekh \& Nissen, 2011, p. 95), and activity theory can be used as an effective analytical tool in action research (e.g., Boey \& Fong, 2013; Stuart, 2014; Thorgeirsdottir, 2015).

Action research is done in iterative cycles of plan-act-observe-reflect. In this article we take a closer look at what happened during the enactment part of cycle one (i.e., how the technology tasks were staged by the preschool teachers). The first cycle had more of an open-ended character (i.e., more in the tradition of the preschool way of handling learning/ play) than the following two cycles, which more closely resembled that of a school assignment and revolved around a narrower subject matter of opening/closing.

It is the act itself - the staging of the technology tasks - that has been the unit of analysis, not the planning of the task or the action research group's joint reflection of said tasks. The analysis in this study was done on an individual level (i.e., single teacher or pair of teachers in the inhouse technology tasks). The data for our study consists of five implemented inhouse technology tasks. Each activity consisted of one or two preschool teacher/s and four children. The inhouse technology activities were approximately 1 to $1.5 \mathrm{~h}$ long and were all video recorded. The task that was the basis for our empirical material could 
be described as a teacher-led construction task. This task revolved around constructing/ designing a model house out of cardboard boxes and cardboard using primarily screws, nuts and bolts, but also other material and construction tools (these tools should not be confused with tools from a mediating artifact perspective). The task connected to the picture book/tv-series characters of The Frog and his Friends (developed by Max Velthuijs), which all of the units had as their ongoing theme at the moment of the data collection. To discern how the tasks were staged, we took our stance in activity theory and the concepts of mediating artifacts, rules and division of labor (the teacher's role) (Table 1).

The action research group decided that screws, nuts, bolts, cardboard and cardboard boxes should be the construction material available to the children and that some kind of tools for hole making were also needed. The consensus in the group was that it would be optimal to contextualize the tasks by connecting it in some way to the present theme at the preschool (i.e., that of the Frog and the Friends) and prepare the children for the tasks by touching on the concept of houses in some way (e.g., technology walks, cf. Bjurulf, 2013). Learning in preschool should never lose the child's perspective, but in this study, we have mainly focused on the teacher's role, not the children's. However, an overall inspection of the empirical data shows that the children were active participants in the tasks and seemed to view them as meaningful and interesting (cf. Sheridan \& Williams, 2018).

\section{Analysis}

In order to identify how the teachers supported the children in the construction task, we searched for recurring patterns in the teacher's actions-what we call didactic actions. In order to discern these didactic actions, we used activity theory in combination with thematic analysis.

The coding process of thematic analysis has sometimes been criticized for being a tad too arbitrary (Boyatzis, 1998), but using the well-defined categories of mediated artifacts, rules and division of labour from activity theory, presented us with a framework for identifying the codes (i.e., the sub-categories of mediated artefacts, rules and division of labor) in the data material in a reliable way. According to Braun and Clarke (2006), the process of thematic analysis can be described with the following steps-familiarizing oneself with the data, coding the material, identifying the common themes, reviewing the themes, and lastly defining and conveying the themes. It was during the first two steps-familiarizing oneself with the data and coding the material - that activity theory came into play. The analysis started with looking at the data material through the categories of mediating artifacts, rules and division of labor (the teacher's role). Even though familiarization started during the video recording of the five construction tasks (which was done by author 1), this step was mostly done through repeated viewings of the five different tasks video recorded by author

Table 1 The tasks at the five units were structured as follows

\begin{tabular}{llll}
\hline Unit & Teacher/s & Children & Age \\
\hline A & Eva and Lena & 4 girls (A1-A4) & 5 \\
B & Susanne & 4 boys (B1-B4) & 4 \\
C & Jenny and Sara & 2 girls, 2 boys (C1-C4) & 5 \\
D & Anna and Malin & 2 boys, 2 girls (D1-D4) & 3 \\
E & Carina & 2 girls, 2 boys (E1-E4) & 3 \\
\hline
\end{tabular}


1. During these viewings, author 1 wrote down brief summaries of what was happening on screen (i.e., the interaction/communication between the preschool teachers, the children and their surrounding). These summarizations were done from a multimodal perspective, where deeds were as important as words, and where a whole sequence of events constituted a multimodal interaction (cf. Norris, 2011). This process resulted in an initial mapping of the categories. This mapping was then exemplified by excerpts from the transcripts and run by author 2 and 3. Agreement was reached for some of the sub-categories. For the ones where an accord wasn't reached, a discussion between the authors ensued that resulted in either a stay of category or a somewhat revised definition of category. This new mapping of sub-categories was then used as a lens by author 1 as the video recordings were once more reviewed. In this process, some sub-categories were re-defined and were once again discussed with author 2 and 3 until consensus was reached.

After all of the data material had been mapped out in codes, the step of identifying common themes ensued. Preliminary themes were identified by author 1; preliminary themes were discarded; preliminary themes were collapsed into one another or split in two, and so on. This resulted in initial themes of didactic strategies that cut across the categories of mediating artifacts, rules and division of labor. These initial themes, and accompanying excerpts, were then run by author 2 and 3. Just like with the codes, agreement was reached for some of the themes, and for others the discussions resulted in a re-definition. One of the leading aspects in these discussions revolved around patterns in the framing of the tasks in the different preschool units. Using this revised set of themes, the coded material was once more examined by author 1 , which again resulted in some new, folded or split themes. This whole process was done iteratively until consensus was reached between the authors, and the final themes were identified. This then, concluded the step of reviewing the themes.

\section{Ethical considerations}

From an ethical perspective, children are viewed to be in a particularly vulnerable situation-many may still be too young to consider whether they really want to participate in the research or not. It is customary to get a written consent of approval from parents/ legal guardians as well as talk to the children so they are aware that their participation in the research/task is voluntary. For this study, a consent form (describing the how's and why's of the study) was sent to all parents/legal guardians, and only the children whose parents/legal guardians had signed this form were considered for inclusion in the filmed tasks. All parents/legal guardians were also invited to an information meeting about the study, which was held by author 1 and one of the preschool teachers. The children who participated in the tasks were selected by the preschool teachers from the ones that had gotten approval from their parents/legal guardians. Just before the filming of the tasks, author 1 talked to the children about why he was visiting the preschool and also showed them the video recorder. Author 1 also tried to be observant during the tasks of whether some of the children were interested in leaving. It should be noted that some of the youngest children in the tasks sometimes asked when it was time to go outside to play, or when it was time to eat. In these instances, author 1 let the preschool teacher handle the situation, primarily because of their contextual history and understanding of the children. In some instances, they encouraged the children to press on with the task, while in other instances they let the children leave the task. To make sure that the content of the tasks wasn't exclusive to these children, the teachers created similar tasks for other children at later dates. All of the 
children and preschool teachers that appear in this article have been made anonymous (i.e., their real names have been changed).

\section{Results}

Using the well-defined categories from activity theory-mediating artifacts, rules and division of labor - as a springboard, we were able to sift through the vast amount of data from each task (the five preschool units) and structure it into sub-categories. The following tables present:

(a) the different mediating artifacts we found in the data material. As described earlier, we differentiate between physical mediating artifacts (i.e., tools), and verbal interactional mediating artifacts (i.e., semiotic signs),

(b) what kind of rules that seemed to govern the tasks,

(c) what kind of roles the preschool teachers took on.

Using these categories and sub-categories as a basis (i.e., as codes), we could then return to the data material and employ a thematic analysis, which resulted in themes of qualitatively different didactic actions on how the teachers framed and brought about the construction task. These actions could be defined as to engage, to guide, to coordinate and to show. One sole interaction sequence between teacher and child can of course contain multiple didactic actions. For example, a teacher may herself use a nut and bolt to show a child how to screw on the nut clockwise, and at the same time verbally guide the child on how the process is done in a clockwise manner. The teachers did not use the different didactic actions equally during the activities - some of the didactic actions were used more than others. However, the focus of the analysis has been on trying to discern all of the different didactic actions that teachers employ in construction tasks in preschool (Tables 2, 3, $4,5)$.

\section{To engage}

The teachers tried in a couple of different ways to contextualize the construction task in relation to the children's earlier experiences. One way of doing this was to connect the task to the present theme at the preschool - that of the Frog and the Friends. As shown in Boström (2018), one of the reasons the teachers gave for adding this material had to do with getting the children more emotionally engaged in the task. The teachers did this either by having a more casual discussion about the present theme with the children, or by roleplaying as the characters from the books about the Frog and the Friends. For example, in unit B, Susanne introduced the task by taking on the role of the Pig from the picture book series. The children sat in front of her on the floor and Susanne moved a small figurine of the Pig in her lap.

Susanne: 'Hi, my friends! Today I have an assignment for you. Me and all of the Friends live in a single box for the moment. The Frog, I, the Hare, the Rat and the Duck. It is so crowded, could you help me in building a house, where all of us have room to live together?' 
Table 2 Physical mediating artifacts

\begin{tabular}{|c|c|c|c|c|c|}
\hline Physical mediating artifacts & A & B & $\mathrm{C}$ & $\mathrm{D}$ & $\mathrm{E}$ \\
\hline Bolts & $\mathrm{X}$ & $\mathrm{X}$ & $\mathrm{X}$ & $\mathrm{X}$ & $\mathrm{X}$ \\
\hline Screws & $\mathrm{X}$ & $\mathrm{X}$ & $\mathrm{X}$ & $\mathrm{X}$ & $\mathrm{X}$ \\
\hline Nuts & $\mathrm{X}$ & $\mathrm{X}$ & $\mathrm{X}$ & $\mathrm{X}$ & $\mathrm{X}$ \\
\hline Spacers & $\mathrm{X}$ & & $\mathrm{X}$ & $\mathrm{X}$ & \\
\hline Hinges & $\mathrm{X}$ & & $\mathrm{X}$ & $\mathrm{X}$ & \\
\hline Pen/pencil & & & $\mathrm{X}$ & & \\
\hline L-shaped irons & & & & $\mathrm{X}$ & \\
\hline Cardboard & $\mathrm{X}$ & $\mathrm{X}$ & $\mathrm{X}$ & $\mathrm{X}$ & $\mathrm{X}$ \\
\hline Cardboard boxes & $\mathrm{X}$ & $\mathrm{X}$ & $\mathrm{X}$ & $\mathrm{X}$ & $\mathrm{X}$ \\
\hline Hole puncher & $\mathrm{X}$ & $\mathrm{X}$ & $\mathrm{X}$ & $X$ & $\mathrm{X}$ \\
\hline Scissors & $\mathrm{X}$ & $\mathrm{X}$ & $\mathrm{X}$ & $\mathrm{X}$ & \\
\hline Screwdrivers & $\mathrm{X}$ & $\mathrm{X}$ & $\mathrm{X}$ & & \\
\hline Awls & & $\mathrm{X}$ & & & \\
\hline Different tables (material and construction) & $\mathrm{X}$ & & $\mathrm{X}$ & & \\
\hline Figurines (The Frog and his friends) & & & $\mathrm{X}$ & $\mathrm{X}$ & $\mathrm{X}$ \\
\hline Pictures of houses & & & $\mathrm{X}$ & $\mathrm{X}$ & \\
\hline Letter from the frog & & & $\mathrm{X}$ & & \\
\hline Paper for sketching and writing & & & $\mathrm{X}$ & & \\
\hline
\end{tabular}

Table 3 Verbal interactional mediating artifacts

\begin{tabular}{|c|c|c|c|c|c|}
\hline Verbal interactional mediating artifacts & A & B & $\mathrm{C}$ & $\mathrm{D}$ & $\mathrm{E}$ \\
\hline Connecting the assignment to the present theme at the preschool & $\mathrm{X}$ & $\mathrm{X}$ & $\mathrm{X}$ & $\mathrm{X}$ & $\mathrm{X}$ \\
\hline Guiding questions on the usage of the tools and the material & $\mathrm{X}$ & & $\mathrm{X}$ & & $\mathrm{X}$ \\
\hline Guiding questions about the intent of construction & $\mathrm{X}$ & & $\mathrm{X}$ & $\mathrm{X}$ & $\mathrm{X}$ \\
\hline $\begin{array}{l}\text { Using correct terms for the tools and the material, and acknowl- } \\
\text { edge when the children use the terms }\end{array}$ & $\mathrm{X}$ & & $\mathrm{X}$ & $\mathrm{X}$ & $\mathrm{X}$ \\
\hline Connecting to earlier discussions about houses & & $\mathrm{X}$ & & $\mathrm{X}$ & $\mathrm{X}$ \\
\hline Connecting to earlier technology walk experience & $\mathrm{X}$ & & & $\mathrm{X}$ & \\
\hline Taking the role of the frog and his friends & $\mathrm{X}$ & $\mathrm{X}$ & & & $\mathrm{X}$ \\
\hline Demonstrating hands-on how the tools and material can be used & $\mathrm{X}$ & & $\mathrm{X}$ & $\mathrm{X}$ & $\mathrm{X}$ \\
\hline
\end{tabular}

Table 4 Rules

\begin{tabular}{|c|c|c|c|c|c|}
\hline Rules & A & B & $\mathrm{C}$ & $\mathrm{D}$ & $\mathrm{E}$ \\
\hline The problem-solving aspect of the activity should be a joint mission for the children & $\mathrm{X}$ & & $\mathrm{X}$ & $\mathrm{X}$ & $\mathrm{X}$ \\
\hline $\begin{array}{l}\text { Every child shall explore and familiarize themselves with the construction tools and } \\
\text { material }\end{array}$ & $\mathrm{X}$ & $X$ & $\mathrm{X}$ & $\mathrm{X}$ & $\mathrm{X}$ \\
\hline The construction shall connect to the theme of the Frog and the Friends & $\mathrm{X}$ & $\mathrm{X}$ & $\mathrm{X}$ & $\mathrm{X}$ & $\mathrm{X}$ \\
\hline When using sharp tools, the children should get assistance & $\mathrm{X}$ & $\mathrm{X}$ & $\mathrm{X}$ & $\mathrm{X}$ & \\
\hline
\end{tabular}


Table 5 The teacher's role

\begin{tabular}{|c|c|c|c|c|c|}
\hline Teacher's role & A & $\mathrm{B}$ & $\mathrm{C}$ & $\mathrm{D}$ & $\mathrm{E}$ \\
\hline Safekeeper of the sharp tools & & $\mathrm{X}$ & & & \\
\hline Supervisor of the tools and the material & & & & $X$ & $\mathrm{X}$ \\
\hline Arranger of the children's positions (to ensure safety) & $\mathrm{X}$ & & & & \\
\hline Implementor of the children's ideas & & $\mathrm{X}$ & & $X$ & $\mathrm{X}$ \\
\hline $\begin{array}{l}\text { Director-guiding the children in describing and connecting their different } \\
\text { ideas }\end{array}$ & $X$ & $\mathrm{X}$ & $\mathrm{X}$ & & \\
\hline $\begin{array}{l}\text { Director-spotlighting the children's attention to what the other children are } \\
\text { doing }\end{array}$ & $\mathrm{X}$ & & $\mathrm{X}$ & $X$ & $\mathrm{X}$ \\
\hline Supporter-encouraging children to help out with each other's quandaries & $\mathrm{X}$ & & & & \\
\hline
\end{tabular}

And in unit C, Sara handed over a letter from the Frog to the children, wherein the Frog asked the children to help him build a house that he and all of the Friends could live in together.

Sara: [Reads from the letter to the four assembled children] 'We're in need of your help to build a house that all [emphasis] of us friends can live in together.'

/---/

Sara: How many should fit in the house now again? It was...

C1: The Frog.

Sara: The Frog.

C1-C4 in unison: The Pig

Sara: The Pig.

C1-C4 in unison: The Hare

Sara: The Hare.

Another way of engaging the children in the task was to connect to their earlier experiences of everyday technology related to the task. Some of the teachers did this by reminding the children about some prior task or tasks (e.g., searching for houses on the net or going for a technology walk and looking for different kinds of houses) in order to draw parallels between "real" construction and the construction task at hand. To stimulate the children's recollection, the teachers often used physical or digital photos. The following excerpt from unit $\mathrm{D}$ can be used to highlight this.

Malin: And here is a house that was built out of wood [shows a photo of a house on the iPad]. We looked at many houses - at how they were built. And in this house [swipes to a new photo], which was built of bricks - in this house, many families lived.

D1: Yes.

The actual artifacts in the construction task were also used as a way of helping the children draw parallels between the task and everyday uses of said artifacts. Like Eva and Lena did by reminding the children of their previous technology walk.

[A1 through A4 are gathered around a table with the teachers.]

A1: What's the name of these [points at a hinge]?

Eva: Yeah, what is that? Pick them up and let's take a look [A1-A3 pick up a hinge each]. 
A2: You can bend it. I think it's something from a door.

Lena: A thing for opening a door, yes, exactly.

Eva: Do any of you remember-A2-do you remember what the name of it is? Do you remember that we took photos of these things?

A2: Mm. Yes, but I don't remember the name.

Sara and Jenny on the other hand, connected the hinge to everyday use by using the surroundings of the actual construction task.

[C1-C3 is standing around the construction table, C3 has just fastened the hinge to a piece of cardboard]

C3: I managed to fit it in... [looks at the construction in his hand containing the cardboard and hinge].

Sara: Does it work?

C3: $\mathrm{Mm}$.

Sara: Have you seen the big hinges we have on our doors [turns to the patio door]you can't see them on that one, but on the door over there... [points to the door that leads to the main assembly room]. Look over there, children, where Jenny is [points towards Jenny who has gone over to the door and is pointing at one of the hinges].

Some of the teachers were also observant of the children commenting on their hands-on experience of the material and engaged the children by asking follow-up questions. Like Eva and Lena did when the children talked about using a screwdriver.

A1: I am not that good at using a screwdriver [holds up a screwdriver in the air].

A2: I'm not good either, it's only my dad who is good at it. He builds stuff.

Lena: Does he often build things?

A2: Mm, he helped grandpa with the toilet downstairs. He helped grandpa... with the sink.

----/

Eva. Did they replace sinks??

A2: No... yes, they changed them!

Or like how Carina did at the beginning of the task in unit $\mathrm{E}$ when she showed the nuts and bolts to the 3-year-olds, and they immediately brought up their parents.

Carina: ... and you're going to build the house. And you can use these kinds of cardboard boxes [shows a box for the children], and then you shall use screws and nuts [shows a plastic box containing nuts and bolts for the children]. Have you seen these kinds of screws before?

E3: No.

E4: Yes.

Carina: You have, E4?

E4: Yes.

E3: My mom has used those kinds of screws for hammering those things you (inaudible) flowers on.

Carina: Your mom has nailed those things you put flowers on?

E3: Yes.

Carina: Maybe these trellises they can grow on [makes a vertical movement with her hands]?

E3: Yes.

/---/ 
Carina: But you know what? These screws are not made for use with a hammer like nails are [hammers in the air with her hand].

E3: Nope.

\section{To verbally guide}

When it came to the more hands-on aspect of the task (i.e., the children's usage of the tools and the construction material), as well as how they could go about solving the larger problem of constructing the house for the Frog and the Friends, we differentiate between to verbally guide and to show. In the former, the teachers use the children's' constructions actions as a springboard to verbally help them along in the process of constructing the final product. In the latter, it is the teachers themselves that are taking the actions.

In the following excerpt we see how Carina verbally instructs a child in combining nuts and bolts. The aspect that is singled out is that the material only works clockwise.

Carina: Have you tried turning it in both directions?

[E3 starts turning the nut clockwise]

Carina: Look! It works.

Another aspect was the "fitting" of the nuts and bolts (i.e., that the diameter is the same) and in the following excerpt Eva is verbally guiding a child in finding suitable nuts and bolts.

Eva: It feels like perhaps it (i.e., the nut that A4 is trying to fasten) is too big, see if you can find a smaller one. You can look for one in this box [reaches for the box with nuts and bolts].

/---/

[A1 has put a lot of nuts in front of her on the table.]

A1: We need some screws [reaches for the box with screws, nuts and bolts].

Lena: Do you find any screws?

A1: I will gather...

Lena: Do you find any that fits?

A1: I'll test and see.

[A1 tests if a screw fits in one of the holes of the hinge-and it's a perfect fit.]

A1: This fits! It fits! [Shows it to Lena.]

Lena: Check it out! Good! And have you found any that fits [Turns to A3]?

[A3 shakes her head.]

Lena: See if you can find any.

The teachers also verbally guided the children in how to go about the actual construction of the house. In the following excerpt we see how Malin is helping the children along in the construction process (i.e., solving the problem for the Frog and the Friends).

Malin: Should we try to connect a wall on the opposite side as well?

A1: Mm.

/---/

Malin: Are we in need of more walls [Picks up a cardboard and holds it on the opposite side of the wall that is already fastened with nuts and bolts]? 
The teachers also verbally guided the children in singling out what constitutes a house by highlighting major important aspects of a building, like Sara and Jenny did by using the children's sketching of the planned house to highlight different parts of a house.

Sara: What are you drawing, C1?

C1: A house.

Sara: A house. And now?

C1: The windows.

Jenny: Mm.

Sara: The windows. How do you know how the windows look, are those like the ones you have at home?

[C1 nods]

/---/

C4: We need a door as well.

Jenny: Yes, exactly. Perhaps you can do that [hands the sketch over to C4].

\section{To show}

In all of the tasks, the preschool teachers focused on the children's understanding of how the construction material and tools worked and could be used to construct the house. As stated before, this was partly done by verbally guiding the children's exploration of the material but was also done by instructing and showing the children exactly how the tools and material should be used. It was also done by highlighting different types of houses for the children.

In the following excerpt we see how Carina introduces nuts and bolts for the 3-year-olds.

Carina: And then we have screws that are not sharp (i.e., not pointy). They have something here that is called a nut [emphasis] [holds up a nut and bolt in front of the children and screws off the nut.]

E3: Can I do that?

Carina: Yes, you can try [hands over the nut and bolt to E3].

E2: I also want to try.

E4: And me too.

Carina: And then you can do like this, E3. Hold on, I'll show you. It's best that I show how it is done first [addresses all four children].

Carina: Here is the screw and here is the nut [holds the bolt and nut in each hand in front of the children], and then you can screw it on like this [shows how it is done.]

[E3 picks up a bolt and nut]

Carina: You can try this one [gives a nut and bolt to E2]. And you can try this one, E1. And you can try this one, E4.

[E1-E4 try screwing the nut on and off from the bolt]

The teachers also 'showed' the children the correct names of the material by using the right nomenclature for the physical mediating artefacts (e.g., nuts, bolts, screwdrivers) and often acknowledged when the children did this as well. In the following excerpts we first see how Malin states the names of the artifacts when introducing them in a methodical manner to the 3-year-olds in unit $\mathrm{D}$, and then how Sara is emphasizing the correct nomenclature during the construction process in unit $\mathrm{C}$.

Malin: Here we have something called L-shaped irons [takes one of the L-shaped 
irons and holds it in front of the children]. And here we have something that is called spacers [holds it in front of the children]. Here we have a lot of screws [holds the box in front of the children], bolts you can say as well.

D1: Bolts [takes a bolt and holds it up in the air].

Malin: And here we have nuts.

/---/

Sara: Look and see if you can find anything to use as well, D2.

[D2 goes over to the box and grabs a hinge.]

Sara: Did you find anything that fits? Ah, you suggest a hinge [emphasis].

In the following excerpt, it is the 5-year-olds themselves in unit A that state the name of the artifacts when Lena introduces them, and Lena highlights the correct names by restating what the children just said.

A1: Screws.

Lena: Screws. And what is this [holds up a nut].

A1: Nuts.

Lena: Nuts.

The task revolved around constructing a house that the Frog and Friends could live in together. "Living together" can of course be interpreted in many ways and there are multiple ways to construct a building that can house a lot of individuals. Some of the teachers focused on showing different designs of houses to children by using digital or physical photos.

C1: I am making the house for the Frog.

Sara: Are you thinking that the Frog should live at the top floor? Should the duck live below... or should he live next door? You have to decide on that.

/---/

Sara: [Turns around and picks up two photos, shows the photos to the children] You will have to decide together if you want to have them (i.e., the rooms that the children are constructing out of boxes) on top of each other, like in a storied building [points to the photo of a storied building] or /.../ if they should be next to each other [points to a photo of a single flat building].

\section{To coordinate}

All the teachers actively engaged in coordinating the children's actions. At the start of all the tasks (units A through E), the teachers informed the children that the construction of the house and the problem-solving aspects should be considered as a collaborative venture. This was then reinforced during the remainder of task A and C, and at least halfway through $\mathrm{D}$ and $\mathrm{E}$ (until some of the children lost interest in the task), but was only stated in the beginning of B. The reinforcement was explicated by stating that this should be seen as the premise of the task (e.g., 'remember that you should solve the problem together'), like we see Lena doing when she took on the role of the Frog:

Lena: You four, will—-together-build one [emphasis] for me and my friends.

Susanne more or less did the same in unit B, where she had the children on the floor in front of her and the figurine in her hand and told them that the mission was to design $a$ house. 
Susanne: 'Hi my Friends! Today I have an assignment for you. The Friends and I live in a single box for the moment. The Frog, I, the Hare, the Rat and the Duck. It is so crowded, could you help me build a house where all of us have room live together?'

In line with the collaborative emphasis, the teachers took on the role of the facilitator of the children's cooperative effort. This was either done by helping the children describe their ideas of how to build the house to each other (in order to help them identify different alternatives on how to proceed) or by asking them if they were in agreement during construction-like Lena and Eva is doing in the following excerpt:

A2: I am thinking this can be 'airholes' (i.e., air conditioning) [Makes a hole in the box with a screwdriver].

A4: Yes, on the side...

A2: Yeah, on the side there are some 'airholes'.

Lena: Have you checked with the others (i.e., A1 and A3) if they also think that this [touches the box with one hand] is what will be the house?

When the children focused on constructing (or talked about wanting to construct) separate parts of the house (e.g., a room, a door, or a wall), some of the teachers tried to help them to coordinate the different parts into a whole product. This was often done by first helping the children connect their construction ideas, and then by discussing how this should be done from a construction perspective (e.g., "it needs to be solid and durable", "which assembly method can we use?"). The following excerpt is an example of the former (i.e., connecting the children's construction ideas).

C1: [Picks up a cardboard shoebox] If we cut away this [points at the bottom of the shoe box], then we can use it as the roof, then the roof will have text on it [points at text at the bottom of the shoe box].

Jenny: Aha! Bring it over to the black table.

[C1 and C3 bring the two cardboard shoe boxes over to the table]

[Sara, Jenny, C1, C2 and C3 gathers around the table with the shoe boxes in front of them]

Jenny: What is your idea, C3? What was your idea with this [pulls the lid off the cardboard shoe box]?

C3: To make the door.

Jenny: Ah, you were thinking that you could make the door from that.

C1: But then we need an opening [meaning door opening], so one can enter-so the hare can enter, because he has... [raises both hands in the air].

Jenny: Mm-hmm.

Sara: Ah, you're thinking about his ears.

C1: Yes.

Sara: Perhaps he can lower his head, so his ears won't get stuck in the door... or the frame.

/---/

[C1 is trying to cut out a doorway with a pair of scissors in another shoebox]

Sara: Should we try to put the two together in some way? If we don't, we will have a separate door (i.e., the other shoe box that was discussed) and a separate roof.

And in the following excerpt we see Malin and Anna discussing with the children about how the different parts can be assembled.

D2: This is the floor [points at the bottom of the cardboard box on the table]. 
Malin: Mm, exactly. What do we need more than a floor in the house?

D2: Eh, a roof.

Anna: Mm.

Malin: A roof!

D1: Yes, that we must have.

Malin: How shall we construct the roof?

D1: We need nails.

/---/

Malin: ...but we don't have any nails, but we have screws.

\section{Discussion}

The majority of the preschool teachers in our study guided the children's work, both from a 'operational-perspective' (i.e., how to use the tools and combine the material) (cf. Fleer, 2000; Plowman et al., 2010) and from a 'intent of construction-perspective' (cf. Walan et al., 2020). Our analysis shows that the teachers in our study took on the role of the guiding hand and through guiding questions and scaffolding tried to enhance the children's learning (i.e., help the children develop construction skills and collaborative skills). This is in line with what has been observed earlier by Siraj-Blatchford and Siraj-Blatchford (1998), Campbell and Jobling (2008) and Thorshag and Holmqvist (2018). In this regard, and in contrast to what Thorshag and Holmqvist (2018) and Plowman et al. (2010) describes (i.e., that preschools teachers are anxious about tasks being too school-like), the teachers in our study did not seem to have any problem with taking on the role of the instructor. During the planning sessions (see Boström, 2018), they even talked about it as being vital for fulfilling the curriculum goals, especially considering the content matter being somewhat new for their respective unit. Plowman and Stephen (2007) note that adults have a critical role of assisting preschool children by helping them in their learning process when interacting with technology (in Plowman's and Stephen's case-digital technology), what they call guided interaction. According to Plowman (2016), guided interaction includes "providing supportive assistance /.../ showing interest, asking questions, making suggestions, or being physically present." (p. 103). When it comes to guided interaction, Campbell and Jobling (2008) found that a common way of encouraging preschool children's problemsolving process was to pose questions like How do you think we could do that? These kinds of questions were also commonly used in our study.

As it did for Sundberg et al. (2016), activity theory as an analytic tool helped us identify structures in a large amount of data. Even though our three analytical categories-mediating artifacts, rules and the teachers' role-are often intertwined and represent different aspects of a holistic whole, they helped us define how the teachers framed, and brought about the learning process in the technology tasks. Through this analysis, we were able to identify four common themes of didactic actions the teachers used to bring about the technology task. These four can be described as to engage, to guide, to coordinate and to show. We have, in the matrix below, further organized and exemplified these strategies with regards to the task as a process; the task as a product; and the task as concepts. The common themes can more or less be described as general-didactic, and by breaking down these further by using process, product and concepts, we were able to discern what they meant from a more technology didactic perspective. Process, product and concepts were derived from DiGironimo's (2011) aspect of Technology as a Creation Process. Due to the nature 


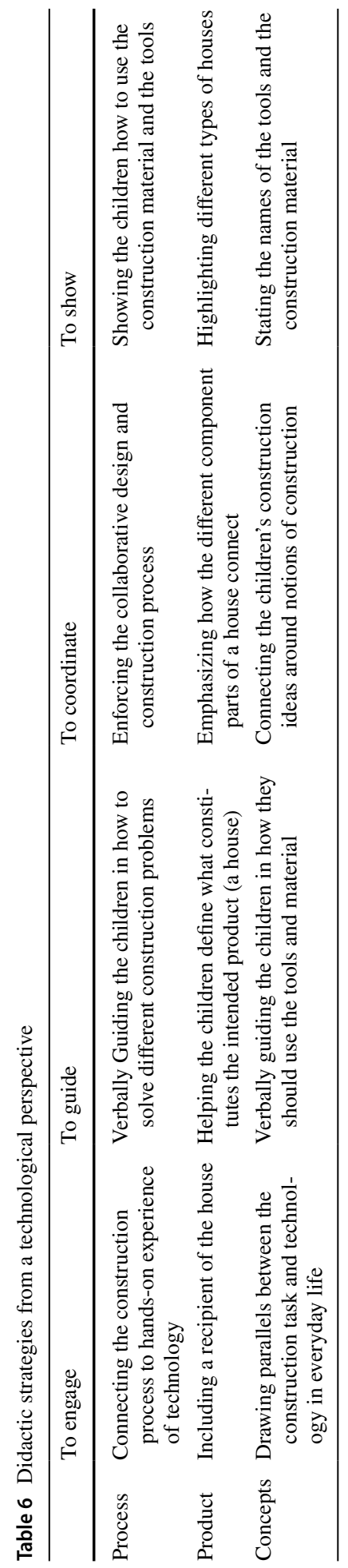


of the construction task (i.e., revolving around the creation process), the other aspects from DiGironimo's prism were not focused upon in any prevalent way by the preschool teachers. According to DiGironimo (2011), Technology as a Creation Process includes skills and knowledge that are needed to engage in design activities in order to complete the envisioned end product - which we have divided into process, product and concepts (Table 6).

The technology task in this study can be defined as a teacher-led construction task with a clear content matter, and with a semi-open-ended structure. The importance of the child initiated free play has been stressed as an important part in making a task meaningful and interesting (e.g., Milne, 2013). However, the majority of the children in the five tasks were very interested in the construction activity at hand and seemed to find it meaningful. During a follow-up meeting (see Boström, 2018) two of the preschool teachers (Eva and Lena) reported that the children who took part in task A wanted to continue working after lunch, and the other children in their unit kept asking when it would be their turn to make a 'technology house'. Furthermore, in the planning session, all the preschool teachers said that they thought the children would be interested in the task for about 20-30 min tops. In the end, the majority of the children in unit A through E worked intensely for 1 to $1.5 \mathrm{~h}$.

Our study shows that when preschool teachers take an active role in technology tasks about construction, they use a variety of didactic actions to help the children's learning process regarding different perspectives of technology (i.e., process, product, concepts). When Sundqvist and Nilsson (2018) examined preschool teachers' and childcare attendees' views of technology education in preschool, they found that the respondents mainly saw their role in construction tasks as being that of the provider of the material and the one setting up a creative environment for the children. The respondents did not generally see themselves as having the role of the guiding and supporting hand in the children's technological learning. As we have shown in our results, this may be a problematic stance to have as a preschool teacher when engaging in technology tasks. Without the guiding adult important aspects of technology may be lost to the children.

\section{Conclusions and further research}

In accordance with what earlier research has pointed out (e.g., Campbell, 2010; Mawson, 2007; Siraj-Blatchford \& Siraj-Blatchford, 1998; Stables, 1997; Walan et al., 2020), this study highlights the importance of the preschool teacher taking an active role in construction activities in preschool. However, this study also digs deeper into what that active role may mean from a technology didactic standpoint. Our research points to a map that combines general didactic strategies (i.e., to engage, to guide, to coordinate and to show) with technology specific areas (i.e., process, product and concepts), which results in specific construction didactic strategies. This didactic map is one step closer to answering the question of how construction tasks in preschool can be designed and used by preschool teachers in supporting children's technological learning (e.g., Fleer, 2000). This, combined with the fact that construction is a central part of the preschool activities (e.g., Sundqvist \& Nilsson, 2018), leads us to conclude that our findings can play an integral role in future preschool teacher education - in both pre-service and in-service education. The map can be used as a kind of didactic toolbox when discussing and planning construction activities.

The preschool teachers' didactic strategies have been the main focus in this study. This is undoubtedly only one part of the interaction taking place in a construction activity in preschool. We suggest further research takes a closer look at the children's construction 
focused actions during construction activities and additionally at how the teachers navigate the children's different technology experiences and construction ideas.

Funding Open access funding provided by Linnaeus University.

Open Access This article is licensed under a Creative Commons Attribution 4.0 International License, which permits use, sharing, adaptation, distribution and reproduction in any medium or format, as long as you give appropriate credit to the original author(s) and the source, provide a link to the Creative Commons licence, and indicate if changes were made. The images or other third party material in this article are included in the article's Creative Commons licence, unless indicated otherwise in a credit line to the material. If material is not included in the article's Creative Commons licence and your intended use is not permitted by statutory regulation or exceeds the permitted use, you will need to obtain permission directly from the copyright holder. To view a copy of this licence, visit http://creativecommons.org/licenses/by/4.0/.

\section{References}

Bairaktarova, D., Evangelou, D., Bagiati, A., \& Brophy, S. (2011). Early engineering in young children's exploratory play with tangible materials. Children Youth and Environments, 21(2), 212-235.

Bjurulf, V. (2013). Teknikdidaktik i förskolan. Studentlitteratur.

Boey, G., \& Fong, F. S. (2013). Incorporating activity theory into action research-does it lead to effective action research outcomes? Sainsab, Journal of the Association of Science and Mathematics Education Penang, 16, 107-122.

Boström, J. (2018). Teknik i förskolan-att motverka traditionella könsroller: En aktionsforskningsstudie. Linköping University Electronic Press.

Boyatzis, R. E. (1998). Transforming qualitative information: Thematic analysis and code development. Sage.

Braun, V., \& Clarke, V. (2006). Using thematic analysis in psychology. Qualitative Research in Psychology, 3(2), 77-101.

Broström, S., Sandberg, A., Johansson, I., Margetts, K., Nyland, B., Frøkjær, T., Kieferle, C., Seifert, A., Roth, A., Ugaste, A., \& Vrinioti, K. (2015). Preschool teacher's views on children's learning: An international perspective. Early Childhood Development and Care, 185(5), 824-847.

Caiman, C. (2015). Naturvetenskap i tillblivelse: Barns meningsskapande kring biologisk mångfald och en hållbar framtid. Stockholms Universitet.

Campbell, C. (2010). The technological knowledge of early childhood pre-service educators. In TERC 2010: Proceeings of the $6^{\text {th }}$ Biennial International Conference on Technology Education Research-Knowledge in Technology Education (pp. 83-91).

Campbell, C., \& Jobling, W. (2008). Technology education in early childhood settings. In H. E. Middleton \& M. B. Pavlova (Eds.), Exploring technology education: Solutions to issues in a globalized world. Nathan: Griffith University.

Daniels, H. (2004). Activity theory, discourse and Bernstein. Educational Review, 56(2), 121-132.

DiGironimo, N. (2011). What is technology? Investigating student conceptions about the nature of technology. International Journal of Science Education, 33(10), 1337-1352.

Ekström, K. (2007). Förskolans pedagogiska praktik: Ett verksamhetsperspektiv. Umeå: Print \& Media.

Elvstrand, H., Hallström, J., \& Hellberg, K. (2018). Vad är teknik? Pedagogers uppfattningar om och erfarenheter av teknik och teknikundervisning i förskolan. NorDiNa, 14(1), 37-53.

Engeström, Y. (1993). Developmental studies of work as a testbench of activity theory: The case of primary care medical practice. In S. Chaiklin \& J. Lave (Eds.), Understanding practice: Perspectives on activity and context (pp. 66-103). Cambridge University Press.

Engström, Y. (2001). Expansive Learning at Work: Toward an activity theoretical reconceptualization. Journal of Education and Work, 14(1), 133-156.

Fleer, M. (2000). Working technologically: Investigations into how young children design and make during technology education. International Journal of Technology and Design Education, 10, 43-59.

Flewitt, R., Hampel, B., Hauck, M., \& Lancaster, L. (2009). What are multimodal data and trancsription? In C. Jewitt (Ed.), The Routledge handbook of multimaodal analysis (pp. 40-53). Routledge.

Ginner, T. (1996). Teknik som skolämne. In T. Ginner \& G. Mattson (Eds.), Teknik i skolan: Perspektiv på teknikämnet och tekniken (pp. 16-40). Studentlitteratur. 
Halliday, M. A. K. (2014). Halliday's introduction to functional grammar (4th ed.). Routledge.

Hallström, J., Elvstrand, H., \& Hellberg, K. (2014). Gender and technology in free play in Swedish early childhood education. International Journal of Technology \& Design Education, 25(2), 137-149.

Hardman, J. (2005). Activity theory as a framework for understanding teachers' perceptions of computer usage at a primary school level in South Africa. South African Journal of Education, 25(4), 258-265.

Hashim, N. H., \& Jones, M. L. (2007). Activity theory: A framework for qualitative analysis. In 4th International Qualitative Research Convention (QRC), 3-5 September, 2007, PJ Hilton, Malaysia.

Herr, K., \& Anderson, G. L. (2005). The action research dissertation: A guide for students and faculty. Sage.

Issroff, K., \& Scanlon, E. (2002). Using technology in higher education: An activity theory perspective. Journal of Computer Assisted Learning., 18, 77-83.

Jarvis, T., \& Rennie, L. J. (1998). Factors that influence children's developing perceptions of technology. International Journal of Technology \& Design Education, 8(3), 261-279.

Jewitt, C. (2009). Different approaches to multimodality. In C. Jewitt (Ed.), The Routledge handbook of multimaodal analysis (pp. 28-39). Routledge.

Keirl, S. (2006). Ethical Technological Literacy. In J.R. Dakers (Ed.), Defining Technological Literacy Towards an epistomological framework (pp81-102). Palgrave Macmillan: New York.

Kress, G. (2009). What is mode? In C. Jewitt (Ed.), The Routledge handbook of multimaodal analysis (pp. 54-67). Routledge.

Kress, G., \& van Leeuween, T. (2006). Reading imagegs: The grammar of visual design. Routledge.

Mawson, B. (2007). Factors affecting learning in technology in the early years at school. International Journal of Technology and Design Education, 17, 253-369.

Mawson, B. (2013). Emergent technological literacy: What do children bring to school? International Journal of Technology and Design Education, 23, 443-453.

Milne, L. (2013). Nurturing the designerly thinking and design capabilities of five-year-olds: Technology in the new entrant classroom. International Journal of Technology and Design Education, 23, 349-360.

Murphy, E., \& Rodriguez-Manzanares, M. A. (2008). Using activity theory and its principle of contradictions to guide research in educational technology. Australsion Journal of Educational Technology, 24(4), 442-457.

Norris, S. (2009). Modal density and modal configurations: Multimodal actions. In C. Jewitt (Ed.), The Routledge handbook of multimaodal analysis (pp. 78-90). Routledge.

Norris, S. (2011). Identity in (inter)action: Introducing multimodal (inter)action analysis. De Gruyter Mouton.

Parker-Rees, R. (1997). Making sense and made sense: Design and technology and the playful construction of meaning in the early years. Early Years, 18(1), 5-8.

Plowman, L., \& Stephen, C. (2007). Guided interaction in pre-school settings. Journal of Computer Assisted Learning, 23(1), 14-26.

Plowman, L. (2016). Learning technology at home and preschool. In The Wiley handbook of learning technology (pp. 96-112). Wiley Blackwell.

Plowman, L., Stephen, C., \& McPake, J. (2010). Supporting young children's learning with technology at home and in preschool. Research Papers in Education, 25(1), 93-113.

Pramling Samuelsson, I., \& Asplund Carlsson, M. (2008). The playing learning child: Towards a pedagogy of early childhood. Scandinavian Journal of Educational Research, 52(6), 623-641.

Rohaan, E., Taconis, R., \& Jochems, W. (2010). Reviewing the relations between teachers' knowledge and pupils' attitude in the field of primary technology education. International Journal of Technology \& Design Education, 20(1), 15-26.

Roth, W.-F., Radford, L., \& LaCroix, L. (2012). Working with cultural-historical activity theory. Forum: Qualitative Social Research, 13(2), 23.

Rönnerman, K. (2010). Aktionsforskning-En väg mot kvalitet och förbättring. In Aktionsforskning i förskolan: trots att schemat är fullt. Lärarförbundets Förlag.

Rönnerman, K. (2012). Vad är aktionsforskning? In K. Rönnerman (Ed.), Aktionsforskning i praktiken: Förskola och skola på vetenskaplig grund (pp. 21-40). Studentlitteratur.

Scollon, R., \& Scollon, S.W. (2009). Multimodality and language: a retrospective and prospective view. In C. Jewitt (Ed.), Routhledge handbook of multimodal analysis (pp. 170-180). Routledge.

Sellander, S. \& Kress, G. (2010). Design för lärande: ett multimodalt perspektiv. Norstedts.

Senesi, P.-H. (1998). Technological knowledge, concepts and attitudes in nursery school. Retrieved from https://hdl.handle.net/2134/1436

Sheridan, S., \& Williams, P. (2018). Sammanfattning och slutsatser. In S. Sheridan \& P. Williams (Eds.), Undervisning I förskolan: En kunskapsöversikt (pp. 6-13). 
Siraj-Blatchford, J., \& Siraj-Blatchford, I. (1998). Learning through making in the early years. In J. S. Smith \& E. W. L. Norman (Eds.), IDATER 98: International conference on design and tecgnology educational research and curriculum development (pp. 32-36). Loughborough University.

Skolverket. (2018). Curriculum for the Preschool-Lpfö 18. Norstedts Juridik.

Smith, P. K., \& Pellegrini, A. (2008). Learning through play. Encyclopedia on Early Childhood Development, 24(8), 61 .

Somekh, B., \& Nissen, M. (2011). Cultural-historical activity theory and action research. Mind, Culture, and Activity, 18(2), 93-97.

Stables, K. (1997). Critical issues to consider when introducing technology education into the curriculum of young learners. Journal of Technology Education, 8(2), 50-65.

Sundberg, B., Areljung, S., Due, K., Ekström, K., Ottander, C., \& Tellgren, B. (2016). Understanding preschool emergent science in a cultural historical context through activity theory. European Early Childhood Education Research Journal, 24(4), 567-580.

Sundqvist, P., \& Nilsson, T. (2018). Technology education in preschool: Providing opportunities for children to use artifacts and to create. International Journal of Technology and Design Education, 28, $29-51$.

Sundqvist, P. (2019). Tre förskollärares undervisning i teknik-en utvecklingspedagogisk analys av det avsedda och det manifesta lärandeobjektet three preschool teachers' teaching in technology—an analysis of the intended and the enacted object of learning. Nordic Studies in Science Education, 15(2), 114-127.

Stuart, K. (2014). Activity theory as a reflective and analytic tool for action research on multi-professional collaborative practice. Reflective Practice, 15(3), 347-362.

Sylva, K., Taggart, B., Siraj-Blatchford, I., Totsika, V., Ereky-Stevens, K., Gilden, R., \& Bell, D. (2007). Curricular quality and day-to-day learning activities in pre-school. International Journal of Early Years Education, 15(1), 49-65.

Säljö, R. (2008). Lärande i människans landskap. In H. Rystedt \& R. Säljö (Eds.), Kunskap och människans redskap: teknik och lärande (pp. 13-27). Studentlitteratur.

Thorgeirsdottir, H. (2015). Investigating the use of action research and activity theory to promote the professional development of teachers in Iceland. University of Exeter.

Thorshag, K. \& Holmqvist, M. (2017). Construction technology in preschool. In The 12th conference of the European science education research association-ESERA.

Thorshag, K. \& Holmqvist, M. (2018). Pre-school childrens expressed technological volition during construction play. International Journal of Technology and Design Education (published online).

Turja, L., Endepohls-Ulpe, M., \& Chatoney, M. (2009). A conceptual framework for developing the curriculum and delivery of technology in early childhood. International Journal of Technology and Design Education, 19, 353-365.

Vallberg, A.-C. (2002). De yngre barnens läroplanshistoria. Studentlitteratur.

Van Aalsvort, J. (2004). Activity theory as a tool to address the problem of chemistry's lack of relevance in secondary school chemical education. International Journal of Science Education, 26(13), 1635-1651.

Walan, S., Flognman, J., \& Kilbrink, N. (2020). Building with focus on stability and construction: Using a story as inspiration when teaching technology and design in preschool. Education, 48(2), 174-190.

Wertsch, J. V. (1998). Mind as action. Oxford University Press.

Westlander, G. (2006). Researcher roles in action research. In K. A. Nielsen \& L. Svensson (Eds.), Action and interactive research: Beyond practice and theory (pp. 45-61). Shaker Publishing.

Publisher's Note Springer Nature remains neutral with regard to jurisdictional claims in published maps and institutional affiliations. 